\title{
LAND USE IN PREHISTORIC MALTA. A RE-EXAMINATION OF THE MALTESE 'CART RUTS'
}

\begin{abstract}
Summary. This paper explores the manufacture and function of the so-called 'cart ruts' within the harsh environment of Malta and proposes that they were deliberately constructed in order to push the boundaries of available arable land and are better identified as field furrows. Using comparative ethnographic evidence as well as archaeological data from European contexts, it is argued that the driving force, which necessitated their manufacture in Malta, lay in socio-economic pressures. It is argued that the ruts are of high antiquity, products of Temple Period intensification and marginalism in land use.
\end{abstract}

\section{INTRODUCTION}

To the Maltese historian, Abela $(1647,69)$, the so-called 'cart ruts' were just as puzzling then as they are today. They have always been interpreted as tracks left by some form of vehicle, but the term 'cart rut' may, in fact, be a misnomer when applied to all of the cuttings. Abela's testimony clearly demonstrates that they belong to a more distant past, but when they were made and to whom they should be attributed are matters that have perplexed archaeologists working in Malta, particularly over the last decade. As Bonanno $(1993,64)$ wrote, 'The enigmatic cart ruts are too obvious in the Maltese rocky landscape to be ignored in any work.'

In a very real sense, it is a risky business to challenge the entrenched view that the ruts found in the largest islands, Malta and Gozo, are the by-product of transport (Trump 1998, 34). Risky, simply because no theory, which has been proposed since 1647, has gained general acceptance. Many thousands of words have been written concerning the ruts as tracks worn by some form of ancient vehicle and perhaps just as many studies concerning the nature of the vehicles themselves. The few detailed plans that have been made of the ruts indicate that a variety of cuttings scar the barren rock of Malta. Hughes $(1999,66)$ in a recent pilot study that foreshadows a larger survey project, and later Bugeja $(2001,23)$, could be correct when they suggested that the ruts might prove to belong to no single period nor attributable to a single function.

The focus of this study falls on groups of ruts found in evenly spaced and roughly parallel lines. It is argued that these ancient clusters are likely to be the 'fossilized' remains of field furrows. If this can be demonstrated, then we open a window on prehistoric agricultural practices that could be described as expansive. ${ }^{1}$ Detailed fieldwork on both a broad and

1 I am grateful to Críostóir Mac Cárthaigh, Department of Irish Folklore, University College, Belfield, Dublin, for information concerning traditional Irish agricultural practices and to Chandra Jayasuriya, cartographer at the University of Melbourne, who produced the map of Malta. 
detailed scale may prove to be the only way forward to defining just how many different types of ruts exist in Malta and Gozo and when each specific cluster was utilized (Schneider 2001, 16-17).

Malta's remarkable prehistoric past is virtually synonymous with the 23 or more megalithic structures that are scattered across the landscape and two subterranean mortuary complexes at Brochtorff in Gozo and Hal Saflieni in Malta. But other aspects of Temple culture, especially in regard to Temple Period economy, remain somewhat elusive. A large body of useful ethnographic parallels and offshore, comparative archaeological data can be drawn into the discussion, if clusters of ruts can be shown to be field furrows that can be attributed to the Temple Period.

Ruts are spread widely across the main islands; less certain are reports that they once scarred the small islands of Comino and Filfla (Table 1). Only Zammit (1928, 23), some 75 years ago, made a direct connection with agricultural practices. Since then, any connection to working the land has been labelled as secondary, following the line of argument that some unknown cargo was hauled overland leaving vehicle tracks behind (Trump 1990, 32; Trump 1998, 35). What the ancients carted around the islands is less clear, but quarried stone, soil, seaweed, salt, agricultural produce, and so on, have all been suggested.

\section{THE RUTS AS AGRICULTURAL ARTEFACTS}

Requiring explanation are ruts with deep and irregular ' $U$ '- or ' $V$ '-shaped profiles, especially those that occur in large clusters, and how it is that they might have resulted from intense agricultural land use (Bugeja 2001, 24). Ruts with wide, shallow and rectangular profiles may be of Roman or later date formed by wheel-drawn vehicles. But even here the attribution of 'ruts' is doubtful. It should be kept in mind that the Romans as road builders were second to none and it was along their highways that their military prowess surged from Britain in the west to Persia in the east. ${ }^{2}$ It is hard to reconcile that Roman interests would operate on a less technologically advanced level in Malta. Notwithstanding, some grooves in the rock surfaces of Malta may also owe their formation to the natural joints in the bedrock typical of karst topography in limestone. ${ }^{3}$

Although the general assumption is that some form of ancient vehicle has scarred the Maltese landscape, there has been some disquiet about the nature of the vehicles used (Trump 2002, 284-5; Cali 1996). Against this assumption came an important observation by $\mathrm{Schneider}^{4}$ who reminded us that certain ruts have clear signs that they were deliberately cut by hand:

... a short section of cart-rut following the path between Hagar Qim and Mnajdra (GR 495691) revealed a section with pointed impressions, which may be interpreted as evidence for deliberate cart-rut carving with a pick. (Schneider 2001, 16)

2 Many works have been devoted to Roman roads, for example, concerning those in Turkey: French 1980; French 1983; French 1998; Sinclair 1989, vol. II, 220, map on p. 219; also Sinclair 1990, vol. IV, index VI Roman Roads for a full listing relative to his text; Mitford 1998.

3 I am grateful to Dr. W.E. Bamford (Principal Fellow and Associate Professor, Department of Civil and Environmental Engineering, The University of Melbourne) for his comments in regard to the nature of some ruts.

4 I am grateful to Guy Schneider at the University of Berne and the 'Via Storia - Centre for Traffic History' who have provided pictures of the pecked rut found between the Hagar Qim and Mnajdra temples. 
TABLE 1

Location of ruts in the Maltese Archipelago and their proximity to known archaeological sites: Neol = Neolithic, Temp $=$ Temple, $\mathrm{BA}=$ Bronze Age, R-P+ = Romano-Punic period or later. 'Cluster' indicates that the ruts are found in numbers rather than a single pair of furrows. 'Features' refers to specific features of interest concerning the ruts

\begin{tabular}{|c|c|c|c|c|c|c|}
\hline SITE & Neol & Temp & $\mathrm{BA}$ & $\mathrm{R}-\mathrm{P}+$ & Cluster & Features \\
\hline \multicolumn{7}{|l|}{ MALTA } \\
\hline Bahrija & & & • & & & \\
\hline Birzebbugia \& Il-Brolli & & & - & - & & \\
\hline Borg in-Nadur & $\bullet$ & • & • & - & & $\begin{array}{l}\text { ruts head to BA site entrance; 'trickle' } \\
\text { channels }\end{array}$ \\
\hline Borg 1-Imramma & & • & & & & \\
\hline Buskett Gardens & & & & & & on a southern slope \\
\hline Dingli Cliffs & & & $\bullet$ & & & to site entrance \\
\hline Dwejra & & & & & & additional lesser cuttings; on $45^{\circ}$ slope \\
\hline \multicolumn{7}{|l|}{ Falka/Sebbieh } \\
\hline Fawwara & & & & & & on promontory not near ancient site \\
\hline Gebel Ciantar/Bingemma & & & • & & & cut by Punic tombs \\
\hline Ghar Dalam & & & - & & & \\
\hline Ghar Mundu & & & & & & near quarry \\
\hline Ghar Zerriegha & & & & & & cut off at cliff edge \\
\hline \multicolumn{7}{|l|}{ Girgenti-Tal Gholja road } \\
\hline Hagar Qim & & • & & & & ruts outside temple wall \\
\hline Hal Far (Santa Sfia) & & - & & - & & \\
\hline \multicolumn{7}{|l|}{ Il-Hmieri } \\
\hline Il-Qortin tal-Magun & & & & & & faint trail to promontory \\
\hline $\begin{array}{l}\text { Ix-Xaghra ta' Ghar } \\
\text { is-Sigra (Nadur) }\end{array}$ & & & & - & & near Punic tombs \\
\hline \multicolumn{7}{|l|}{ Kalkara, Wied } \\
\hline \multicolumn{7}{|l|}{ Ta' Rinella } \\
\hline Kordin & & • & & • & & \\
\hline \multicolumn{7}{|l|}{ Maghtab } \\
\hline Marsa & & & & - & & \\
\hline Mellieha Bay & & & & & & ruts run into sea \\
\hline Mensija & & - & & & & \\
\hline Minsia, St & & & & & & between Sliema and \\
\hline Julian's heights & & & & & & Birkirkara \\
\hline $\begin{array}{l}\text { Misrah Ghar il-Kbir } \\
\quad \text { (Clapham Junction) }\end{array}$ & & & & • & • & $\begin{array}{l}\text { cut by Punic tombs; near or up to } \\
\text { quarries; on slope }\end{array}$ \\
\hline Misrah Ghonoq & & & - & - & & head toward promontory; on slope \\
\hline \multicolumn{7}{|l|}{ Misrah il-Mielah } \\
\hline Mizieb & & & & & & stop at cave entrances \\
\hline Mnajdra & & • & & & & ruts pecked with pick \\
\hline Mtahleb & & & & • & & \\
\hline Mtarfa & & & - & - & & cut by Punic tombs \\
\hline Nadur, Benjemma area & & & $\bullet$ & • & & two groups \\
\hline Naxxar, San Pawl tat-Targa & & & & & & runs into cistern \\
\hline Qala Hill (Mgarr) & & & $\bullet$ & & $\bullet$ & $\begin{array}{l}\text { head to BA site entrance; lost under } \\
\text { field; near quarry }\end{array}$ \\
\hline Qallilija & & & & • & & on steep slope $45^{\circ}$ \\
\hline Qortin 1-Imdawwar & & • & & & & \\
\hline Rabat & & & & - & & \\
\hline \multicolumn{7}{|l|}{ Roman Villa } \\
\hline Ras il-Gebel & & & • & & & head toward promontory; near quarry \\
\hline Ras il-Pellegrin & & & & & & runs over cliff edge \\
\hline $\begin{array}{l}\text { Salina/Tal Qadi/San Pawl } \\
\text { tat Targa }\end{array}$ & & & & • & & \\
\hline Santa Maria Tal Bakkari & & $\bullet$ & & - & & \\
\hline
\end{tabular}


TABLE 1

continued

\begin{tabular}{|c|c|c|c|c|c|c|}
\hline SITE & Neol & Temp & $\mathrm{BA}$ & $\mathrm{R}-\mathrm{P}+$ & Cluster & Features \\
\hline Skorba (Zebbiegh) & • & • & • & - & • & $\begin{array}{l}\text { stepped sides on ridges; minor 'trickle' } \\
\text { channels }\end{array}$ \\
\hline St George's Bay & & • & • & & & runs into sea \\
\hline \multicolumn{7}{|l|}{ Ta' Blankas } \\
\hline Ta’ Dun Konz & & & & $\bullet$ & • & near quarry \\
\hline & \multicolumn{5}{|c|}{ (Mgarr Barrani) } & \\
\hline Ta' Rozzat & & • & & & & \\
\hline \multicolumn{7}{|l|}{ Ciantar) } \\
\hline Tarxien & & $\bullet$ & $\bullet$ & $\bullet$ & & \\
\hline Wardija ta' San & & & • & & & head toward \\
\hline Gorg & & & & & & promontory \\
\hline Wardija Ta' Zuta & & & $\bullet$ & • & & near quarry \\
\hline Wied Filep & & & $\bullet$ & & & \\
\hline Xemxija Hill & & & & & & pecked by hand \\
\hline \multicolumn{7}{|l|}{ GOZO } \\
\hline \multicolumn{7}{|l|}{ Dejra } \\
\hline Is-Sidra, Qala & & & & & & to promontory; to ruined field walls \\
\hline Ta' Cenc & & $\bullet$ & $\bullet$ & & & near temple 1-Imramma \\
\hline Ras il-Wardija & & & & • & & \\
\hline \multicolumn{7}{|l|}{ Ta Lambert } \\
\hline \multicolumn{7}{|l|}{ COMINO } \\
\hline \multicolumn{7}{|l|}{ Unconfirmed } \\
\hline \multicolumn{7}{|l|}{ FILFLA } \\
\hline Unconfirmed & & & & & & \\
\hline
\end{tabular}

But he was not the first to observe such tool marks - Zammit (1928, 252), later Evans (1934, 339-40) and Hughes (1999, 70-1) made similar statements. Trump (1990, 33, 145) reports pecked ruts at Xemxija Hill, whereas Lewis $(1977,61)$ has also written of additional markings associated with the ruts.

It would be otiose to explore the many arguments concerning the ruts functioning as tracks for vehicles and the nature of the vehicles themselves when Hughes $(1999,70-1)$ has presented a well-reasoned summary of the arguments for and against this function. However, it is worth considering the level of technology required in support of the vehicle argument.

First, whether one accepts a Temple or Bronze Age date for the cuttings, the concept that vehicles produced them runs against the practice of other ancient cultures, which used either human porterage or beasts of burden to transport goods. ${ }^{5}$ Second, it is hard to reconcile that such a high volume of traffic took place, enough to produce the plethora of ruts, given the small size of Malta and Gozo; one should also take into account the limited wear on some of the cuttings (Trump 1990, 34). Third, all known, early, wheeled vehicles, regardless of which ancient culture produced them, were lightly built, serving a military purpose as chariots or

$5 \quad$ Whitehouse and Wilkins 1986,148 , 'A lama can carry a weight of $c .60 \mathrm{~kg}$, a donkey $70-90 \mathrm{~kg}$, a mule 90 $140 \mathrm{~kg}$, and a camel up to $270 \mathrm{~kg}$ (compared to up to $40 \mathrm{~kg}$ for a human porter on easy ground, considerably less over difficult terrain).' 
performing a symbolic role for ceremonial display purposes. Fourth, adhering to vehicle use as an explanation for the ruts presents a 'Catch 22'. Full load-pulling capacity of animals only really became established in the Roman period for two fundamental reasons: roads were well made and animal harnesses were inadequate for the task until that time. Whether slide car or wheeled vehicle, animals shackled into primitive harnesses would not have been able to haul the weight of goods relative to the degree of scoring preserved on the rock faces. And if they were, the ruts hardly seem to qualify as well-made roads of the type known in the Roman or later periods; herein lies the conundrum (Whitehouse and Wilkins 1986, 148).

To date, the most convincing evidence that some ruts were field furrows and others, possibly water channels, is found at Misrah Ghar il-Kbir otherwise known as Clapham Junction. In the plan (Fig. 1) produced by Magro Conti and Saliba, ${ }^{6}$ the clusters of ruts have all the hallmarks of furrows. They are cut in orderly parallel lines - estimates of the distance between them vary in the range of $1.37 \mathrm{~m}$ to $1.41 \mathrm{~m}$ (Zammit 1928, 18; Evans 1971, 202; Trump 2002 , 266). It has been argued that the ruts were made by vehicles hauling stone from rock quarries. But were the quarries large enough to produce the number of ruts around them? An alternate interpretation is that the quarries post-date the ruts and they have in fact partly destroyed them. ${ }^{7}$

It is clear that the Temple Period was a time of unsurpassed technological ability. It can be implied that at this time the islanders possessed some engineering skills and employed levers (Zammit 1994, 15-23; Trump 2002, 80), 'pullies' (Evans 1971, 148, pl. 67, T/S.76), and rollers (Trump 2002, 79-84), as well as possibly exploiting the use of pivots (Evans 1959, 137; Trump 2002, 124), to transport and engineer orthostats into standing positions. Full exploitation of their environment, pushing the boundaries beyond existing arable land, may also have been within their technological grasp. While clusters of ruts may reflect the creation of fields, longer paired lines of ruts, as well as those that intersect and cut other groups, such as at Clapham Junction, may have more to do with the channelling of water (Fig. 1). Water collection and preservation might also explain the lesser cut marks, shallow, thin grooves closely spaced on rock surfaces - 'trickle' channels - in and around ruts at Liskoba (L-Iskorba) (Fig. 2) ${ }^{8}$ as well as those in close proximity to ancient sites such as Borg in-Nadur (Fig. 3), but not obviously near deeper ruts (i.e. near to ruts such as those under discussion). In some areas, ruts clearly act as water channels funnelling into pits before the rut line is again picked up on the opposite side of the pit (Fig. 4). ${ }^{9}$

Ethnographic and archaeological evidence from Europe can help to bridge the void between today's barren rock of Malta and the fertile farmland proposed here for the Temple

6 Magro Conti and Saliba 1998; I am very grateful to P. Saliba for supplying me with the report of the survey of Clapham Junction.

7 Magro Conti and Saliba 1998; also Bonanno 1994, 91-2. I would argue that the quarries B, C, D and E that are shown on the Magro Conti-Saliba plan appear to have destroyed the line of the close-set furrows. Trump 2002, 268, has suggested this line of reasoning for some groups: ' . . there are a few cases where later quarrymen have taken advantage of ruts to make their extraction of stone easier. Here manifestly it was the ruts which came first and the quarrying after, probably long after.'

8 A. Bugeja has also located similar scored edges of ruts at Dwejra; I am grateful to Dr. Bugeja for showing me photographs of the site and for supplying details about the find.

9 Trump 2002, 267, did note that there were examples that 'tapped rain run-off to fill water cisterns', but discounted this as a secondary use of the ruts. Note that he states no ruts are associated with natural water sources; Trump 2002, 268. 


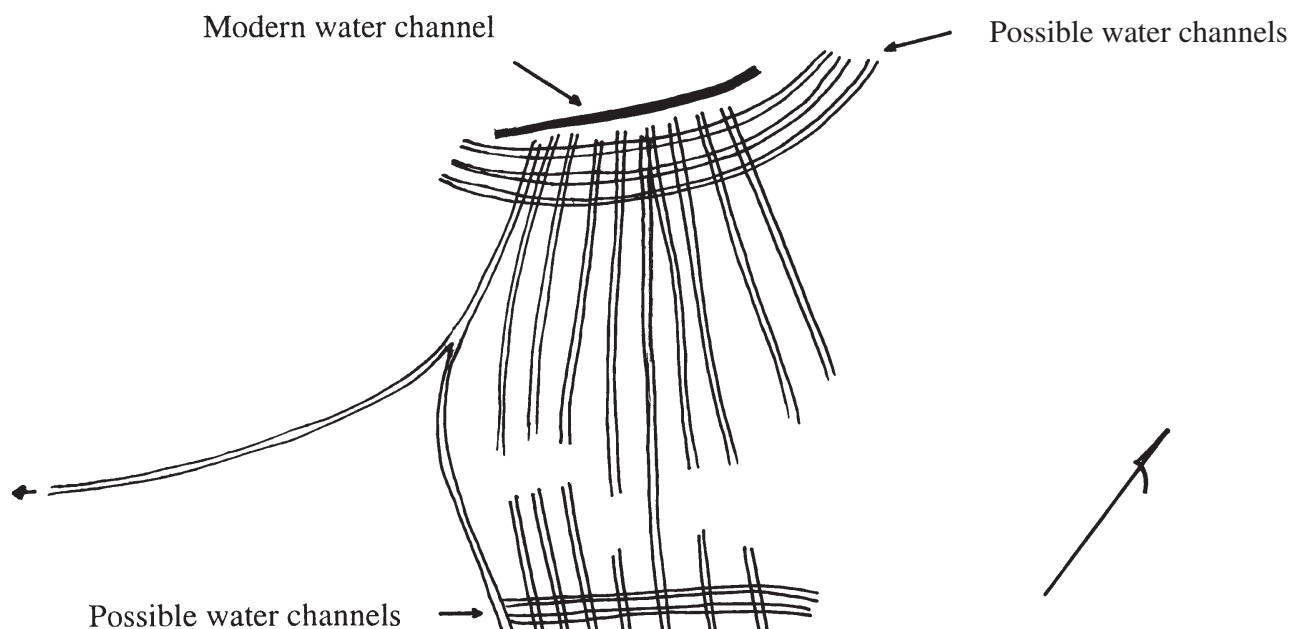

Possible water channel

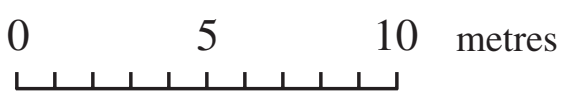

Figure 1

Cluster of ruts at Misrah Ghar il-Kbir ('Clapham Junction') after the detailed plan produced by Magro Conti and Saliba (1998). The arrow on the left indicates where a long line of ruts leads to, or is broken by another quarry. C, $\mathrm{D}$ and $\mathrm{E}$ are ancient or historic quarries as designated by Magro Conti and Saliba.

Period. In more than one respect, the Aran Islands, off the west coast of Ireland, offer some useful grounds for comparison to Malta. Here farmers, in recent history, have demonstrated that soil creation on bare rock is possible in a landscape prone to severe erosion. Despite their differences in latitude, Malta and Aran share certain environmental limitations: both are small in size, both have significant areas that are devoid of vegetation, both have limited water supplies and hence population numbers for both archipelagos have always been subject to natural constraints.

In the book Man of Aran, Pat Mullen describes how Kilbride created farmland on little rocky islands. With paid labourers they, 


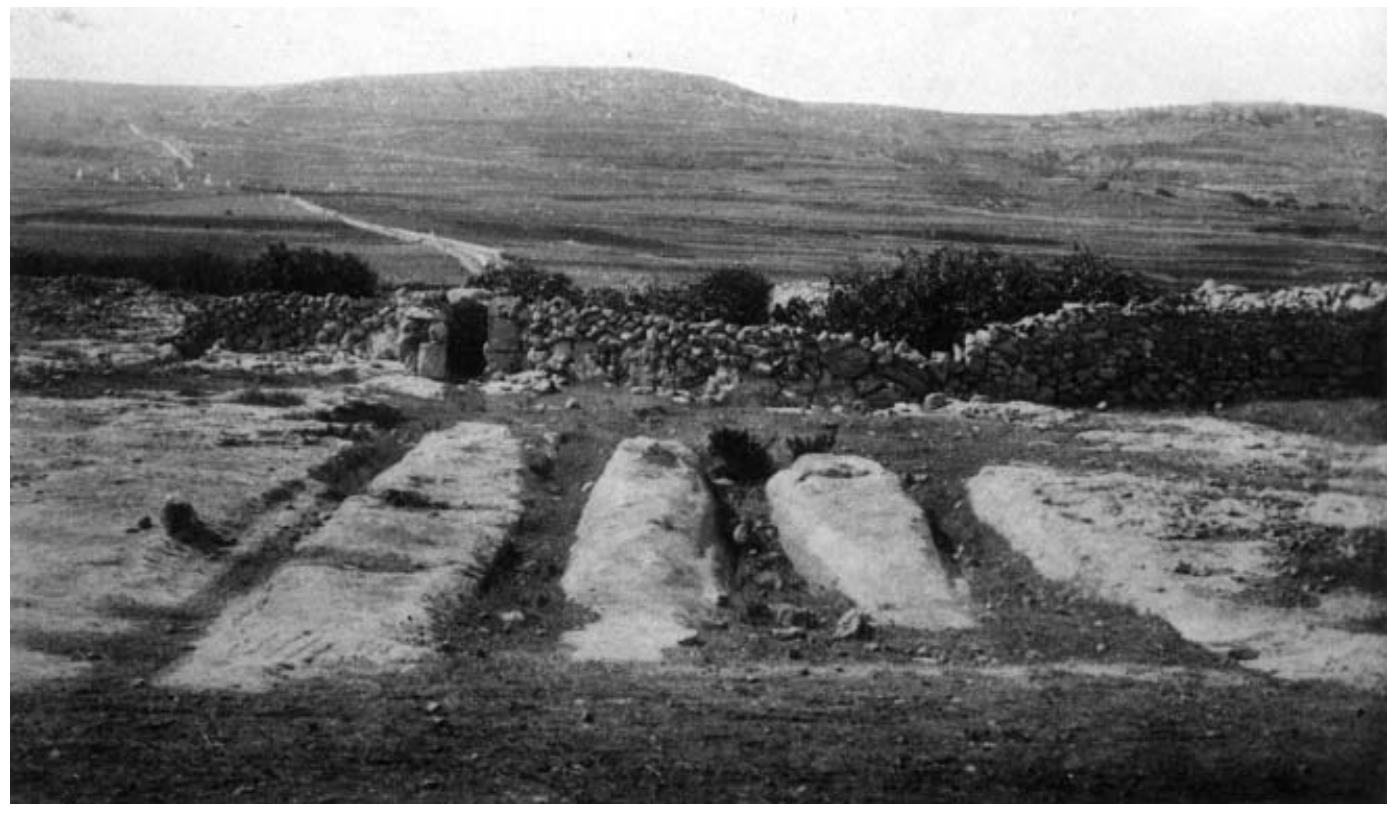

Figure 2

Photograph from M.A. Murray, Excavations in Malta, Part II, pl. XXXIII:4 (1925), depicting rock-cut ruts or furrows at Liskoba (L-Iskorba). Note the lesser, shallow and close-set 'trickle' channels at right angles to the left side of the rut on the left and in the foreground, on the ridge between the first and second ruts from the left.

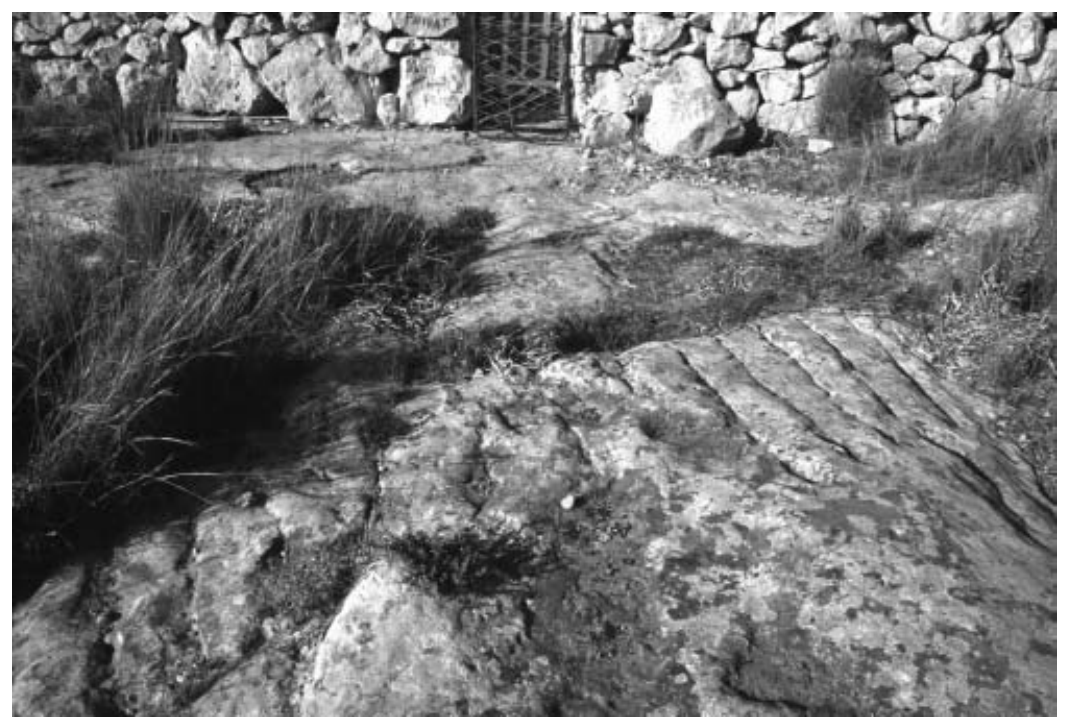

Figure 3

'Trickle' channels running into other, soil-filled cuttings at Borg in-Nadur. 


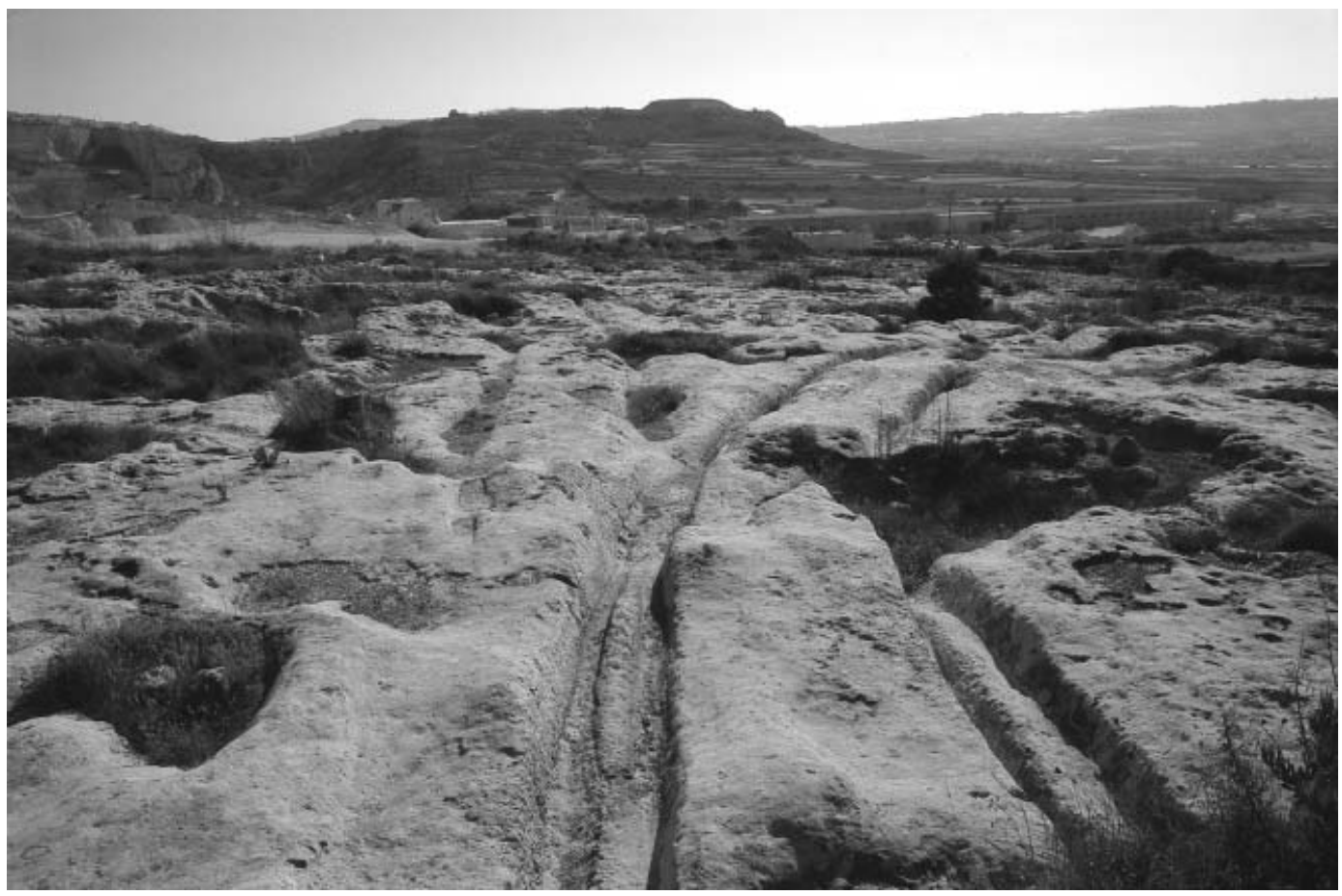

Figure 4

Furrow running down into a pit at Naxxar. The furrow line is again picked up on the far side of the pit.

... dig the mud at low tides, in the dry summer weather, and pile it up on the islands; then he had stones hauled from adjoining crags and filled in the places where the mud had been dug from, until they were level with the islands. A layer of stones, broken small, was spread on top and then the mud placed over all, which, when mixed with seaweed, made a fine rich soil. Finally after some years of work, the farm was made. A few drains ran through it to the shore, at which end they were covered by iron plates backed by heavy stones. (Quoted from Robinson 1989, 123)

In Aran, once the soil was made, ridges over a metre wide called 'lazybeds' are created between pairs of furrows that were cut manually with a spade (Fig. 5). The spade is said to have often hit the underlying rock as the furrows were worked (O'Dowd 1994, 210-11; O'Brien (ed.) 1977, 91-3). Soil that accumulated in the trenches was dug out or turned over onto the ridges in preparation for the next planting. Similar field patterns can be found elsewhere in Ireland where the rows of regular, wide ridges and deep furrows were measured out using a string line or the length of the spade handle as a guide. The regular spacing, kept within an arm's length, facilitated the planting and tending of the crops. ${ }^{10}$ Labour intensive fieldwork and repeated additions of seaweed fertilizer gradually improved the quality of the new soil in Aran. If a similar

10 The size and nature of the plots would suggest the use of hoes rather than ploughs in antiquity as it is in the modern era; Houston 1964, 642. 

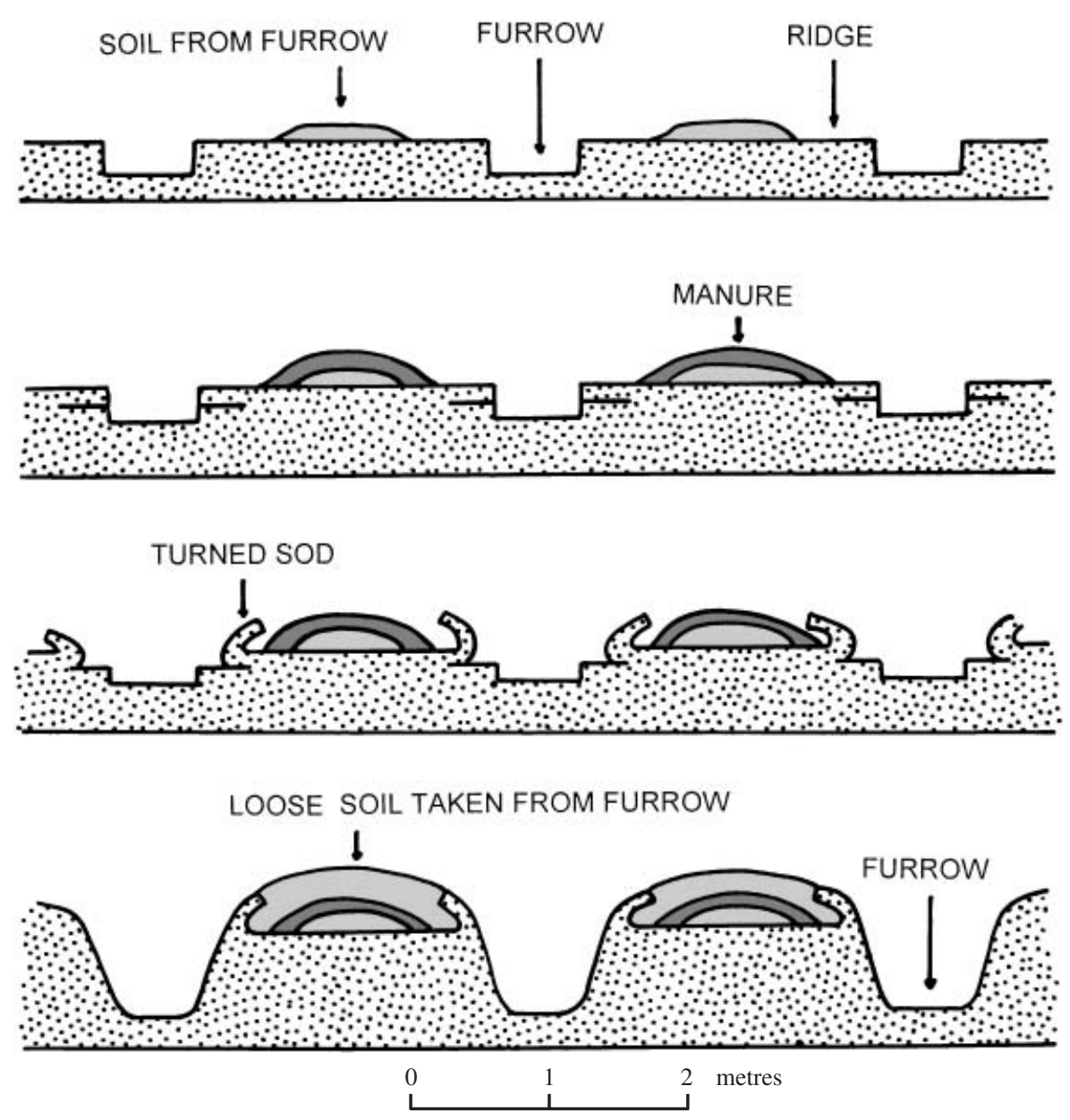

Figure 5

Stages in the manufacture of ridges and furrows, which are cut manually with a spade, Ederney region, Co. Fermanagh, Ireland (after Bell and Watson 1986).

form of farming took place on the rocky surfaces of prehistoric Malta, then it is feasible that once the trenches were cut, they were continually deepened through tilling and clearing. Hence, the irregular depths of some ruts.

Seaweed may have been exploited by ancient societies in Malta, but it has never been tested archaeologically. ${ }^{11}$ On islands, like Aran, where nutrients from animal manure are limited to the number of animals the islands can support, seaweed as a naturally replenishing resource cannot be underestimated. The technology of making soil from sand and seaweed has some chronological depth. Ancient fields with soil that had been made in this way

11 Trump 1990, 32; Trump 2002, 268. It is possible that the murrex shells found in the upper levels at Tas Silg were 'harvested' for the purpose of improving soil from shell middens at St George's Bay where ancient murrex dye works may have been located (Sagona 1999). 
were excavated at Gwithian, a Bronze Age (second millennium BC) beaker settlement in Cornwall, in the south-west corner of Britain (Megaw, Thomas and Wailes 1961; Bradley 1978, 41).

By cutting the rock in Malta, the farmer would have created an artificial and permanent furrow along which water run-off could be channelled and presumably leached nutrients or eroding soil could be preserved. Such practices have been recorded in other ancient contexts. Bradley, for instance, discussed the evidence for furrows in land regeneration at Achnacree Moss:

.. . boundary banks were associated with shallow ditches cut through the underlying podsol, and the excavators suggested that this was done to improve the local drainage and to bring degraded land back into use. (Bradley 1978, 19)

Houston refers to similar measures taken in ancient Latium:

Counter-measures to soil erosion arose very early in Latium, where the deforestation of the Sabine mountains quickly caused rapid down-cutting in the soft tufa of the Campagna. Tunnels or cuniculi were cut by the Etruscans from the sixth century B.C. in southern Etruria and in the Alban Hills, to draw off surface run-off, serving the dual purpose of soil conservation on the slopes and irrigation on the plains. (Houston 1964, 123)

The model presented here for Malta is one of intensive land rehabilitation and soil management; ruts that scar the rock surface at sites like Clapham Junction are areas where rehabilitation ultimately failed. This leaves us with the tantalizing prospect that some existing farm plots in Malta may be enduring success stories. ${ }^{12}$

\section{CHRONOLOGY OF THE RUTS}

The date of the ruts is a most vexing problem. Great antiquity is suggested by those examples that have fallen victim to geological events; some have been cut short at cliff edges, others have been broken by fault lines (Trump 1998, 37; Trump 2002, 265, 268; Mifsud et al. 2000, 79). Punic tombs provide a terminus post quem at c.700 BC for the ruts (Pace 1995, 59), thus discounting the Phoenician-Punic population at the outset as the creators of the cuttings. Some ruts are situated close to Bronze Age sites. Hence, they are usually assigned to this period (Evans 1971, 204; Pace 1995, 59; Trump 1999, 97-8; Trump 2002, 266), although it is significant that an association between rut and settlement has not been established for all sites of this date in Malta (Bugeja 2001, 31). Table 1 summarizes the possible chronological range of ruts, which appear close to archaeological sites (Fig. 6).

If the ruts were formed in the course of creating arable land, then we are compelled by the growing body of evidence for economic practices elsewhere to identify a culture in Malta for which the following points applied. Farming was structured and labour intensive, matched by a farming technology that already included an element of soil management through the

12 Zammit 1928, 21, '. . covering large tracts of rock surface with soil to make fields, caused many carttracus to disappear in part or altogether'; see also Magro Conti and Saliba 1998, 'We absolutely agree with Gracie [1954] who states that a great proportion of cart-ruts disappear under cultivation'. 


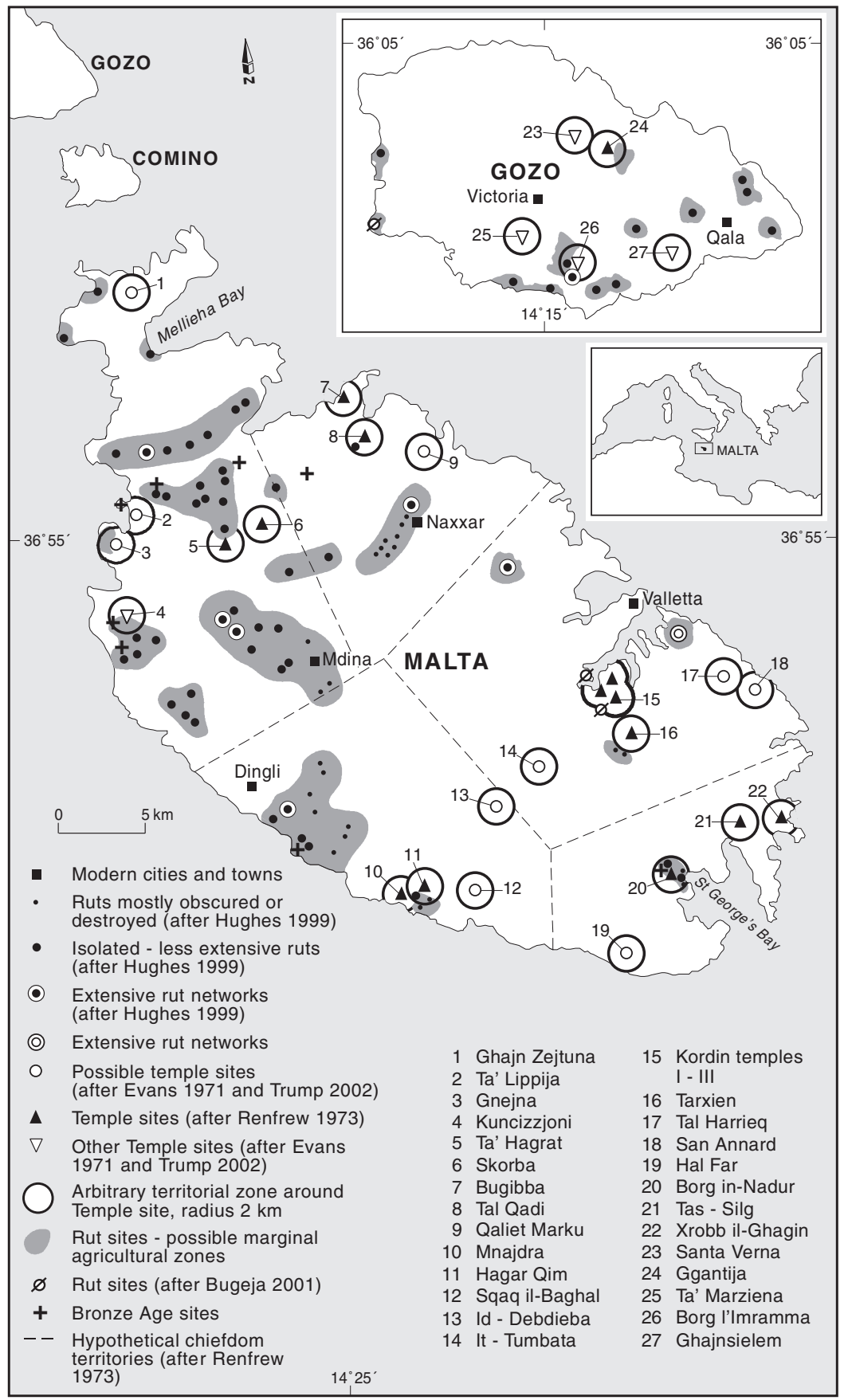

Figure 6

Map showing the distribution of rock-cut ruts or furrows in relation to prehistoric Temple and Bronze Age sites in Malta and Gozo. 
addition of nutrients. ${ }^{13}$ Local knowledge of the land had accumulated through generations of farming in non-marginal areas in Malta. This aspect is important, as it has long been argued that successful innovations in agriculture demanded detailed knowledge of the land. It implies communities were long established in an area before they resorted to agricultural experimentation (Barker 1985, 251; Fowler 1971, 153-82). On these grounds, we could discount the Neolithic and Bronze Age settlers of Malta in favour of Temple societies. ${ }^{14}$ Weather conditions are likely to have been reasonably predictable when fields were developed on the exposed rock surfaces. A collective workforce existed that was able to be organized, ${ }^{15}$ one that was vigorous and was not suffering the effects of an economic downturn. There was assured economic viability while the experiment was put to the test through community or family support. An underlying economic need to expand arable land, one that was imminent or predicted rather than pressing, may have proved the motivation. ${ }^{16}$ Farmers must have anticipated that they would gain considerably by the one-off expenditure of labour in cutting the rock.

If neither the Neolithic, Bronze Age, Phoenician nor later cultures are implicated in the manufacture of the ruts, then we are left to explore evidence for a Temple Period date. Such a time frame has been suggested by others in the past including Zammit $(1928,20)$ and more recently Hughes $(1999,72)$. It is suggested here that cutting the rock in order to create arable land was an extreme response to economic conditions. Changes in agricultural practices are often triggered by stress, most notably by increasing population numbers and shifting climatic conditions. Similarly, the driving force that necessitated such labour-intensive manufacture of new farmland in Malta is likely to have lain in socio-economic pressure. A Temple Period date for the furrows is argued on the basis of population numbers, the degree of social cohesion, organization and specialization implied through their building works, longevity of their culture and proven technological abilities (Renfrew 1973, 117-18; Trump 1999, 98). Maltese society had arrived at the point where it could not 'simply rest on its accomplishments' nor could it 'attempt to maintain its marginal return at the status quo, without further deterioration' (Tainter 1988, 195).

Despite these considerations, proximity to ancient sites may not be helpful in the quest to establish the date of the ruts, especially if we identify them as furrows. Implicit in this function

13 Barley and lentils as well as wheat are attested in Neolithic contexts at Skorba; Helbaek 1966, 53; Evans 1971, 235; Renfrew, J.M. 1972, 144-5. Horsebeans (that is early broadbeans), hulled six-row barley, and lentils were found in Bronze Age samples from Tarxien Cemetery; Renfrew, J.M. 1972, 144-5. Barley and lentils are thought to have simply continued to be grown from the Neolithic period and horsebeans were introduced later; Renfrew, J.M. 1972, 145. Wheat may have been side-lined as 'uneconomical'. Cf. Bradley 1978, 34, who discusses the Neolithic exploitation of the lowland chalk regions of England and the shift from growing wheat to barley because 'it seems that the loess covering the chalk was exhausted within the Neolithic, particularly if the main crop was wheat.' Wheat depletes soil nutrients more rapidly than other crops $(1978,32)$.

14 Stoddart et al. 1993, 5. Cassar 1997, 138, argues that Neolithic would-be farmers changed the natural environment by clearing the sclerophyll forests that included Holm Oak, Aleppo Pine and smaller plant species in the process of clearing arable land. They simply transplanted their existing farming know-how onto a new landscape, which they cleared for the purpose.

15 Estimations of overall population numbers in the Temple Period vary, for example 11,000 (Renfrew 1973, 155) or 12,000 (Cassar 1997, 138) for both Gozo and Malta. The sheer volume of megalithic buildings and their distribution across the islands points to a sizeable work force.

16 Boserup 1965; Boserup 1981. Boserup's model based on her ethnographic study of African farming communities, which she later applied to the archaeological contexts of first millennium Europe, demonstrated that change occurs in low-technology farming practices at times of stress. Also Renfrew 1973, 114-16; Barker 1985, $258-60$. 
is the notion that people were operating outside their usual agricultural boundaries, stepping up the intensity of their land use by occupying marginal areas. Not surprising in this light is the ample evidence of ruts, which exist in areas devoid of ancient settlements (Table 1) (Hughes 1999, 74; Bugeja 2001, 31-2). What degree of influence, if any, the greater Mediterranean region had on Temple Period economy is not clear (Sherratt 1994, 199). It cannot be discounted that trade networks and marine resources may have experienced a decline and have contributed to the failure of Temple economy (Hughes 1999, 76).

It is certainly the case that drystone walls were employed around small farm plots on the Aran Islands, to help contain the soil they created. Considering that some of the clusters of rock-cut furrows are situated on sloping ground ${ }^{17}$ it is probable that soil creation went hand-inhand with the construction of drystone field walls. Whether or not this will be proved probably falls to future archaeological investigations, but an observation by Bugeja is very significant in this regard:

At Is-Sidra in Qala, Gozo (GR 394789), a long trail [of ruts] may be traced directly to/from remains of rubble constructions at the tip of the promontory. The latter remains, which could be related to the underlying agricultural landscape, contain no evidence for use in the Bronze Age. (Bugeja 2001, 31)

At some point in time, probably approaching the mid-third millennium, the Temple economy began to unravel. Because Malta's land resources are so obviously finite, the creation of new arable land in the Temple Period would have satisfied immediate or predicted economic demand. Without expanding beyond Malta's shores, there may have been no way to build on what they had already achieved in terms of agricultural productivity. The Temple Period is thought to have ended abruptly around $2500 \mathrm{BC}$, triggered by total economic collapse and depopulation of the islands to some degree (Evans 1971, 224; Bonanno 1993, 44). 'Collapse' in this instance fits hand-in-glove with Tainter's definition,

... the gradual deterioration or depletion of a resource base (usually agriculture), often due to human mismanagement, and the more rapid loss of resources due to an environmental fluctuation or climatic shift. (Tainter 1988, 44)

Without the intensive care of farming communities, erosion would have undone their work, exposing the rock surfaces beneath (Zammit 1928, 23; Schembri 1997, 121).

What Malta's communities suffered at the end of the Temple Period may have resembled the potato famine of Ireland in the 1840s. This disaster, brought about by the potato blight, resulted in massive starvation and pushed many thousands of Irish to emigrate to America ${ }^{18}$ With diminished population numbers in Malta, it would almost be inevitable that the drystone field walls would have fallen into disrepair and the cycle of erosion and soil depletion would have begun anew. The arrival of Bronze Age immigrants would appear to have dealt the final blow that spelt extinction for the Temple culture in Malta (Evans 1959, 168; cf. Trump

17 See illustrations of sloping rock surfaces cut with ruts: Gracie 1954, pl. II:b; Trump 1998, 34; Trump 2002, 281; Zammit 1926 (1952), also in Mifsud et al. 2000, 25; Zammit 1928, pl. II.

18 O'Beirne Ranelagh 1994, 110-28, 'Between 1841 and 1851 the population [of Ireland] fell by nearly 20 per cent ...' (1994, 110). Widespread starvation followed by epidemics of typhus, dysentery, scurvy, hunger oedema, cholera and yellow fever $(1994,111)$ killed well over a million people. Emigration rose sharply 'from 75,000 in 1845 to 250,000 in $1851^{\prime}(1994,112)$. 
1990, 21-2, 48). Hence, any continuity into subsequent cultures has proved hard to identify in the archaeological record (Evans 1959, 168; Trump 1990, 21-2, 48).

Centre for Classics and Archaeology

The School of Art History, Cinema, Classics and Archaeology

The University of Melbourne

Victoria 3010

AUSTRALIA

\section{REFERENCES}

ABEla, Commendatore Fra G.F. 1647: Della Descrittione di Malta Isola nel Mare Siciliano con le sue Antichita, ed altre Notitie (Malta, facsimile edition by the Melitensia Book Club, Midsea Books, Malta 1984).

BARKER, G. 1985: Prehistoric Farming in Europe (Cambridge).

BELL, J. and WATSON, M. 1986: Irish Farming. Implements and Techniques 1750-1900 (Edinburgh).

Bonanno, A. 1993: Tarxien Cemetery. Break or Continuity between Temple Period and Bronze Age in Malta? Mediterrâneo 2, 35-47.

Bonanno, A. 1994: Archaeology. In Frendo, H. and Friggieri, O. (eds.), Malta Culture and Identity (Valletta, Malta, Ministry of Youth and the Arts), 81-103.

BOSERUP, E. 1965: The Conditions of Agricultural Growth (London).

BOSERUP, E. 1981: Population and Technology (Oxford).

BRAdley, R. 1978: The Prehistoric Settlement of Britain (London, Henley and Boston).

BUGEJA, A. 2001: Methods of date assignment for cart-ruts in the Maltese Islands: discussing relationships with Bronze Age fortified settlements on promontories. The Oracle (Journal of the Grupp Arkeologiku Malti) 2, 23-35.

CALI, Y. 1996: The Malta Cart Ruts. <http://www.maltaweb.com/culture/cart_ruts/cart_ruts1.html>

CASSAR, L.F. 1997: Settlement patterns in the Maltese Islands: from early colonization to pre-Independence. GeoJournal 41(2), 137-44.

CUNLIFFE, B. 1974: Iron Age Communities in Britain (London).

CUnLIFFe, B. (ed.) 1994: The Oxford Illustrated Prehistory of Europe (Oxford and New York).

DAWKINS, B. 1918: The Maltese Cart Ruts. Man 18, 87.

EVANS, E.M.P. 1934: Maltese cart-ruts. Antiquity 8, 339-42.

EVANS, J.D. 1959: Malta (London, Ancient Peoples and Places).

EVANS, J.D. 1971: Prehistoric Antiquities of the Maltese Islands (London).

FEnton, E.G. 1918: The Maltese Cart Ruts. Man 18, 67-72.

FOWLER, P.J. 1971: Early prehistoric agriculture in western Europe: some archaeological evidence. In Simpson, D.D.A. (ed.), Economy and Settlement in Neolithic and Early Bronze Age Britain and Europe (Bristol), 153-82.

FRENCH, D.H. 1980: The Roman road system of Asia Minor. In Temporini, H. (ed.), Aufstieg und Niedergang der Römischen Welt: Geschichte und Kultur Roms im Spiegel der neueren Forschung (Berlin), 698-728.

FRENCH, D.H. 1983: New research on the Euphrates frontier: Supplementary notes 1 and 2. In Mitchell, S. (ed.), Armies and Frontiers in Roman and Byzantine Anatolia: proceedings of a Colloquium held at University College, Swansea in April 1981 (Oxford, BAR Int. Ser. 156), 71-101. 
FRENCH, D.H. 1998: Pre- and early-Roman roads of Asia Minor. Iran 36, 15-43.

FRENDO, H. and FRIGGIERI, o. (eds.) 1994: Malta Culture and Identity (Valletta, Malta, Ministry of Youth and the Arts).

GRACIE, H.S. 1954: The ancient cart-tracks of Malta. Antiquity 28, 91-8.

HELBAEK, H. 1966: Report on carbonized grain from AF 5 (GHD. Phase). In Trump, D.H., Skorba, Excavations carried out on behalf of the National Museum of Malta (Oxford, Reports of the Research Committee of the Society of Antiquaries of London, no. 22), 53.

Houston, J.M. 1964: The Western Mediterranean World. An Introduction to its Regional Landscapes (London).

HUGHES, K.J. 1999: Persistent features from a palaeo-landscape: the ancient tracks of the Maltese Islands. The Geographical Journal 165(1), 62-78.

LEWIS, H. 1977: Ancient Malta. A study of its Antiquities (Gerrards Cross, Bucks).

mac Cárthaigh, c. and whelan, K. (eds.) 1999: New Survey of Clare Island. Volume 1: History and Cultural Landscape (Dublin, The Royal Irish Academy).

MAgro CONTI, J. and SALIBA, P.C. 1998: An evaluation of the Archaeological site at 'Misrah Ghar il-Kbir' aka Clapham Junction limits of Rabat with a definition to the function and behaviour of the cart-ruts (Privately distributed). Also in Sunday Times of Malta March (Newspaper) 7 March 1999, 38-9.

matthews, R. (ed.) 1998: Ancient Anatolia. Fifty Years' Work by the British Institute of Archaeology at Ankara (London, British Institute of Archaeology at Ankara).

MEgaW, J.V.S., ThOmas, A.c. and waILES, B. 1961: The Bronze Age settlement at Gwithian, Cornwall: preliminary report on the evidence for early agriculture. Proceedings of the West Cornwall Field Club 2, 200-15.

MifSUd, A., MifSUd, S., AgiUs SUltana, C. and SAVONA VENTURA, C. 2000: Malta. Echoes of Plato's Island (Malta, The Prehistoric Society of Malta).

MITFORD, T. 1998: The Roman frontier on the Upper Euphrates. In Matthews, R. (ed.), Ancient Anatolia. Fifty years' work by the British Institute of Archaeology at Ankara (London, British Institute of Archaeology at Ankara), 255-72.

MURRAY, M.A. (with ThOMPSON, G.C.) 1923: Excavations in Malta, Part I (London).

MURRay, M.A. (with Mitchell, C.A. and WARD, T.J.) 1929: Excavations in Malta, Part III (London).

o’beirne Ranelagh, J. 1994: A Short History of Ireland (2nd ed.) (Cambridge).

o'BRIEN, M. (ed.) 1977: A World of Stone (Dublin).

O'DOWD, A. 1994: Resources and life: aspects of working and fishing on the Aran Islands. In Waddell, J., O'Connell, J.W. and Korff, A. (eds.), The Book of Aran (Newtownlynch, Kinvara, Co. Galway), 194-220. PACE, A. 1995: Malta and the dawn of the metal ages. Treasures of Malta 2(1), 55-9.

RENFREW, C. 1972: Notes and News: Malta and the Calibrated Radiocarbon Chronology. Antiquity 46, $141-4$.

RENFREw, C. 1973: Before Civilization. The Radiocarbon Revolution and Prehistoric Europe (London). RENFrew, J.M. 1972: Cultivated plants from the Tarxien Cemetery, Malta. Antiquity 46, 144-5.

ROBINSON, T. 1989: Stones of Aran (London).

SAGONA, C. 1999: Silo or vat? Observations on the ancient textile industry in Malta and early Phoenician Interests in the Island. Oxford Journal of Archaeology 18(1), 23-60.

SCARRE, C. 1998: Exploring Prehistoric Europe (Oxford, Places in Time series).

SCHEMBRI, P.J. 1997: The Maltese Islands: climate, vegetation and landscape. GeoJournal 41(2), 115-25. SCHNEIDER, G. 2001: Investigating historical traffic routes and cart-ruts in Switzerland, Elsass (France) and Aosta Valley (Italy). The Oracle (Journal of the Grupp Arkeologiku Malti) 2, 12-22. 
SHERRATT, A. 1994: The transformation of early agrarian Europe: the later Neolithic and Copper Ages 4500-2500 BC. In Cunliffe, B. (ed.), The Oxford Illustrated Prehistory of Europe (Oxford and New York), $167-201$.

SIMPSON, D.D.A. (ed.) 1971: Economy and Settlement in Neolithic and Early Bronze Age Britain and Europe (Bristol).

SINCLAIR, T.A. 1989: Eastern Turkey: An Architectural And Archaeological Survey, volume II (London). SINCLAIR, T.A. 1990: Eastern Turkey: An Architectural And Archaeological Survey, volume IV (London). StOdDART, S., BONANNO, A., GOUder, T., MALONE, C. and TRUMP, D. 1993: Cult in an island society: prehistoric Malta in the Tarxien Period. Cambridge Archaeological Journal 3(1), 3-19.

SYNGE, J.M. 1921: The Aran Islands, parts 1-2 (Dublin and London).

TAINTER, J.A. 1988: The Collapse of Complex Societies (Cambridge).

TRUMP, D. 1966: Skorba. Excavations carried out on behalf of the National Museum of Malta (Oxford, Reports of the Research Committee of the Society of Antiquaries of London, no. 22).

TRUMP, D. 1990: Malta. An Archaeological Guide (2nd ed.) (Valletta).

TRUMP, D. 1998: The Cart Ruts of Malta. Treasures of Malta 4(2), 33-7.

TRUMP, D. 1999: The architecture of the Maltese Temples. In Mifsud, A. and Ventura, C. (eds.), Facets of Maltese Prehistory (Mosta, Malta, Prehistoric Society of Malta), 91-100.

TRUMP, D. 2002: Malta prehistory and temples (Malta).

ventura, F. and Tanti, т. 1994: The cart tracks at San Pawl tat-Targa, Naxxar. Melita Historica 11(3), 219-40.

WADDELl, J., O'CONNELL, J.W. and KORFF, A. (eds.) 1996: The book of Aran (Galway).

Whitehouse, R. and Wilkins, J. 1986: The Making of Civilization. History Discovered through Archaeology (London).

WINTHRoP, R.H. 1991: Dictionary of Concepts in Cultural Anthropology (Westport, Connecticut).

ZАмміт, т. 1926: Malta: the Islands and their Prehistory (Reprinted 1952) (Malta).

Zамміт, т. 1928: Prehistoric cart-tracks in Malta. Antiquity 2, 18-25.

Zамміт, т. 1994: Tarxien Temples and Saflieni Hypogeum (Reprint with introduction by K. Mayrhofer) (Malta). 